\title{
Isolation and Characterization of Two Korean Mistletoe Lectins
}

\author{
Tae Bong Kang ${ }^{1}$, Seong Kyu Song ${ }^{1}$, Taek Joon Yoon², Yung Choon Yoo ${ }^{3}$, \\ Kwan Hee Lee ${ }^{1}$, Erk Her ${ }^{4}$ and Jong Bae Kim ${ }^{1, *}$ \\ ${ }^{1}$ School of Food and Biosciences, Handong Global University, Pohang 791-940, Korea \\ ${ }^{2}$ Bio-Food and Drug Research Center, Konkuk University, Chungju City, Chungbuk 380-701, Korea \\ ${ }^{3}$ Department of Microbiology, College of Medicine, Konyang University, Nonsan City, Korea \\ ${ }^{4}$ Department of Immunology, College of Medicine, Konkuk University, Chungju City 380-701, Korea
}

Received 11 April 2007, Accepted 16 July 2007

Two isolectins (KML-IIU and the KML-IIL) were individually isolated from the previously reported Korean mistletoe lectin, KML-C, by using an immunoaffinity column. Molecular weights of the KML-IIU and the KML-IIL were $64 \mathrm{kDa}$ and $60 \mathrm{kDa}$ respectively. Both of the lectins were composed of heterogeneous $A$ and $B$ subunits linked with a disulfide bond, and showed the same carbohydrate-binding specificities for Gal and GalNAc. However, they are different not only in biophysical properties (glycosylation and amino acid compositions) but also bioactivities (cell killing and cytokine induction). The KML-IIL showed 17-145 times stronger in cytotoxicities to various human and mouse cancer cell lines than the KML-IIU. The KML-IIL also induced TNF- $\alpha$ secretion from mouse peritoneal macrophages 4.5 times better than the KML-IIU. The results demonstrated isolectins in Korean mistletoe were varied in bioactivities and the KML-IIL may be developed as an anti-cancer agent.

Keywords: Cytotoxic effect, Glycosylation, Isolectin, Mistletoe, TNF- $\alpha$

\section{Introduction}

Mistletoe extracts have been widely used as anti-cancer agents for various kinds of cancers (Beuth et al., 1992; Friess et al., 1996; Schink, 1997; Steuer-Vogt et al., 2001). Anti-cancer activities of those mistletoe extracts are attributed mainly to lectins in the mistletoe (Hajito et al., 1989; Beuth et al., 1993). Mistletoe lectins consist of A and B subchains linked with a disulfide bond,

*To whom correspondence should be addressed.

Tel: 82-54-260-1350, Fax: 82-54-261-6705

E-mail: jbkim@handong.edu and are classified as ML-I, ML-II, and ML-III, depending on the specificities to kinds of sugars. Many studies have demonstrated the mistletoe lectins show anti-cancer activities in vitro as well as in vivo (Franz et al., 1981; Schumacher et al., 1994; Schumacher et al., 1995; Büssing et al., 1996; Ribereau-Gayon et al., 1996; Ribereau-Gayon et al., 1997).

Although most of the European mistletoe lectins belong to ML-I group (Gal-specific), Korean mistletoe lectin is categorized as ML-II type specific to both Gal and GalNAc (Lee et al., 1999; Yoon et al.,1999). Korean mistletoe lectin-C (KML-C) has shown a strong anti-tumor activity through an apoptosismediated cell killing and/or an immune cell-mediated cell killing (Yoon et al., 2003). An activity of the KML-C in cytokine induction (TNF- $\alpha$, IL-2, IFN- $\gamma$, and IL-4) increases a significant level of antigen-specific cellular and humoral immune responses in mice. (Yoon et al., 2001). In addition, the KML-C has shown strong adjuvant effect on the mucosal immune system. When the KML-C was intranasally administered to mice along with inactivated influenza virus antigens, both humoral and cellular immune responses of the mucosal as well as the systemic immune system were significantly enhanced. The immunized mice were protected from homologous as well as heterologous viral challenges (Song, S. K. and Zina, M., unpublished data).

The KML-C existed as a form of mixture of two lectins, those of which sizes are very alike each other. The KML-C has shown clear discrepancies from the European lectins in molecular weights, sequences of protein and nucleic acids, patterns of glycosylation, and existence of isotypes (Yoon et al., 1999; Park et al., 2001). In order to study underlying mechanisms involved in adjuvant effects of the KML-C, further purification of the KML-C into individual lectins is required. In this paper, we report isolectins (KML-IIU and KML-IIL) purified from the KML-C using an affinity chromatography and their physicochemical properties and bioactivities. Molecular weights of the KML-IIU and the 
KML-IIL were $64 \mathrm{kDa}$ and $60 \mathrm{kDa}$ respectively. In comparison to the KML-IIU, the KML-IIL showed 17-145 times higher cytotoxicity to various human and mouse cancer cell lines, and a significantly higher level of TNF- $\alpha$ release from peritoneal mouse macrophages.

\section{Materials and Methods}

Isolation of KML-C. The KML-C was isolated from Korean mistletoe described previously (Yoon et al., 1999). Briefly, mistletoe leaves were powdered, blended, and extracted in $0.15 \mathrm{M} \mathrm{NaCl}-$ $10 \mathrm{mM}$ sodium phosphate buffer (PBS, pH 7.4) for $8 \mathrm{~h}$ at $4^{\circ} \mathrm{C}$. After centrifugation at $10,000 \mathrm{~g}$ for $20 \mathrm{~min}$, the supernatant was filtered through a Wattman filter paper $(0.45 \mathrm{~mm})$, adjusted to be saturated in $70 \%$ ammonium sulfate, and left for $2-3 \mathrm{~h}$ at $4^{\circ} \mathrm{C}$. The precipitate was dissolved in PBS, dialyzed several times against the same buffer, and then applied to an acid-treated Sepharose column. After washing the column with PBS to remove unbound protein, the bound proteins (KML-C) were eluted with $0.1 \mathrm{M}$ lactose in PBS. The fractions were pooled and dialyzed against PBS and stored at $-20^{\circ} \mathrm{C}$ until used. The purification process was performed under acidic conditions ( $3 \%$ acetic acid) in order to eliminate or significantly reduce any possible endotoxin effect. Possible residual endotoxin was removed further by passing the purified lectin through the Detoxi-Gel Endotoxin Removing Gel (Pierce Biotechnology, Rockford, IL 61105, USA).

SDS-polyacrylamide gel electrophoresis (SDS-PAGE). SDSPAGE was carried out as described elsewhere (Laemmli, 1970). Lectins were electrophoresed in the polyacrylamide gel $(0.1 \%$ SDS and $12.5 \%$ polyacrylamide) after treatment with or without 2mercaptoethanol. Protein bands were analyzed by staining the gel with Coomassie Brilliant Blue R-250.

Preparation of monoclonal antibody specific to KML-IIU. Monoclonal antibodies specific to KML-IIU or KML-IIL were generated as described previously (Kang et al., 2001). Briefly, hybridoma was obtained by fusing spleen cells of the Balb/c mice immunized with purified KML-C with SP2/0 myeloma cells. The fusion cells were cloned by limiting dilutions and the individual cells were amplified by further culturing the cloned cells. The culture supernatant containing antibodies was analyzed for specificity for KML-IIU or KML-IIL by an ELISA. Specific monoclonal antibodies were enriched through a protein-G affinity chromatography.

Preparation of immunoaffinity column and isolation of two lectins from KML-C. KML-IIU-specific monoclonal antibodies were conjugated with the Sepharose in a hydroxysuccinimideactivated hitrap affinity column (NHS, Pharmacia Biotech, Sweden), according to the manufacturer's instruction. Briefly, the KML-C $(1 \mathrm{mg})$ was applied to the immunoaffinity column $(0.7 \times 2.5 \mathrm{~cm}$, volume $1 \mathrm{ml}$, bead structure $34 \mu \mathrm{m}$ ). Initially, unbound proteins (KML-IIL) were collected by washing the column with PBS, and then the proteins bound to the column (KML-IIU) were eluted with glycine-HCl (pH 2.8) buffer. Fractions of the KML-IIL or the KML-IIU were pooled, dialyzed against PBS, and stored at $-20^{\circ} \mathrm{C}$ until used.
Western blot analysis. Lectins electrophoresed through a $12.5 \%$ SDS-polyacrylamide gel were transferred onto a nitrocellulose membrane using a semi-dry type blotter. The nitrocellulose membrane was blocked with PBS containing 5\% non-fat dry milk and incubated with specific monoclonal antibodies $(1: 2500)$. After washing, the blot was incubated at room temperature (RT) with Rabbit anti-mouse IgG conjugated with alkaline phosphates (CAPPEL, 1:1000) and then treated with bromo-4-chloro-3indolyl phosphate/nitro blue tetrazolium (BCIP/NBT).

Hemagglutination and inhibition assay. Human type B red blood cells (RBC) were processed and resuspended in PBS to be $2 \%$ of the blood volume. Using 96-well plates, $50 \mu \mathrm{l}$ of the RBC were mixed with $50 \mu \mathrm{l}$ of medium containing the lectin in two-fold serial dilutions and then incubated for $1 \mathrm{~h}$ at RT. Hemagglutination activity of the lectin was monitored by a light microscopy. For an assay of hemagglutination inhibition, $25 \mu \mathrm{l}$ of lectin solution was mixed with the same volume of carbohydrates in PBS. After incubation for $30 \mathrm{~min}$ at RT, the mixture of lectin and sugar was added to the RBC $(50 \mu \mathrm{l})$ and incubated further for $1 \mathrm{~h}$ at RT.

Detection of glycosylation of lectins. Glycosylation of the purified lectins was identified by using a commercially available kit (DIG Glycan Detection Kit, Roche). Detection of the glycosylation was performed by following the manufacturer's instructions. Briefly, hydroxyl groups in conjugated sugars were oxidized into an aldehyde group by mild periodate treatment. The spacer-linked steroid hapten digoxigenin (DIG) was then covalently attached to this aldehyde group via a hydrazide group. DIG-labeled glucoconjugates were subsequently detected in a DIG-specific ELISA.

Amino Acid composition analysis. Amino acid compositions of the lectins were analyzed using a Pico-Tag Free Amino Acid Analysis column $(3.9 \times 300 \mathrm{~mm})$ and a Waters HPLC system. Lectins were hydrolyzed with $6 \mathrm{M} \mathrm{HCl}$ at $110^{\circ} \mathrm{C}$ for $24 \mathrm{~h}$ in sealed evacuated tubes. The hydrolyzed proteins or free amino acids were derivatized for $15 \mathrm{~min}$ using a specific solution (ethanol/distilled water/triethylamine/phenylisolthiocyanate, $7 / 1 / 1 / 1, \mathrm{v} / \mathrm{v}$ ).

Cytotoxicity test. Various cells were incubated with different concentrations of lectins for $48 \mathrm{~h}$ in 96 well-plates. Survivability of the cells was determined by the XTT (2,3-Bis(2-methoxy-4-nitro-5sulfophenyl)-2H-tetrazolium-5-carboxanilide) method as described previously (Goodwin et al., 1995). Briefly, XTT $(1 \mathrm{mg} / \mathrm{ml})$ and PMS (N-methyl dibenzopyrazine methyl sulfate) $(5 \mathrm{mM})$ were dissolved in a pre-warmed $\left(37^{\circ} \mathrm{C}\right)$ culture medium and in PBS respectively. For cytotoxicity assay, $50 \mu \mathrm{l}$ of the PMS-XTT solution (a mixture of $25 \mu \mathrm{l}$ of the PMS solution and $5 \mathrm{ml}$ of the XTT solution) was added to each well. After incubation for $4 \mathrm{~h}$ at $37^{\circ} \mathrm{C}$ in a humidified atmosphere with $5 \% \mathrm{CO}_{2}$, the plates were measured the absorbance at $450 \mathrm{~nm}$ with a multi-scan plate reader (Pharmacia Bio-Tech.) following a brief shaking.

TNF- $\alpha$ assay. Thioglycollate-elicited macrophages were harvested from the peritoneal lavage of balb/c mice at 4 days post injection i.p. of $2 \mathrm{ml}$ thioglycollate medium (Sigma). The cells were washed with RPMI- 1640 and cultured for $3 \mathrm{~h}$ at $37^{\circ} \mathrm{C}$ with $5 \% \mathrm{CO}_{2}$ in a humidified condition in the same medium supplemented with $10 \%$ 
(v/v) FBS, $2 \mathrm{mM}$ L-glutamine and penicillin/streptomycin (Gibco BRL). Nonadhering cells were removed by washing with ice cold PBS and decanting the solution. The remaining attached cells were then treated with the indicated concentrations of KML-IIU or KML-IIL and incubated further for $24 \mathrm{~h}$. TNF- $\alpha$ released in the culture medium was measured using an ELISA kit (R\&D System).

Protein concentration. Protein concentration was determined by the BCA method (Smith et al., 1985) using a commercially available assay kit (Pierce, NY, USA).

\section{Results and Discussion}

Isolation of two mistletoe lectins. Previously, KML-C was isolated from the extracts of Korean mistletoe (KM110) using Sepharose affinity chromatography (Yoon et al., 1999). As shown in Fig. 1A, the KML-C contained 4 bands under the reducing condition generated by 2 -mercaptoethanol treatment, suggesting that the KML-C is a mixture of two lectins. (Fig. $1 \mathrm{~A}$ and 1D). In order to further purify the lectins from the KML-C, an immunoaffinity column was generated using
KML-IIU-specific monoclonal antibodies (Fig. 1B). The KML-C was individually separated by the immunoaffinity column as indicated in Fig. 1C and 1D. The study revealed that the KML-C was composed of $65 \%$ of KML-IIU and $35 \%$ of KML-IIL. This finding supports the previous report that multiple isotype lectin genes exist in Korean mistletoes (Park et al., 2001), which do not exist in European mistletoes (Wu et al., 1992; Eschenburg et al., 1998; Eck et al., 1999; Bantel et al., 1999; Krauspenhaar et al., 1999).

Biophysicochemical properties of the lectins. The molecular weights of the KML-IIU and KML-IIL were $64 \mathrm{kDa}$ and $60 \mathrm{kDa}$ respectively and each of the isolectins was composed of $\mathrm{A}$ and $\mathrm{B}$ subchains as shown in a reducing condition of treatment with 2-mercaptoethanol (Fig. 1D). Since molecular weights the two lectins were very similar to each other, separation into an individual lectin was not possible at that time (Yoon et al., 1999). The amino acid composition of the isolectins was analyzed using a combination system of an amino acid analysis column and a HPLC. As indicated in Table 1, the two lectins were very similar to each other in amino acid compositions except for minor differences; while
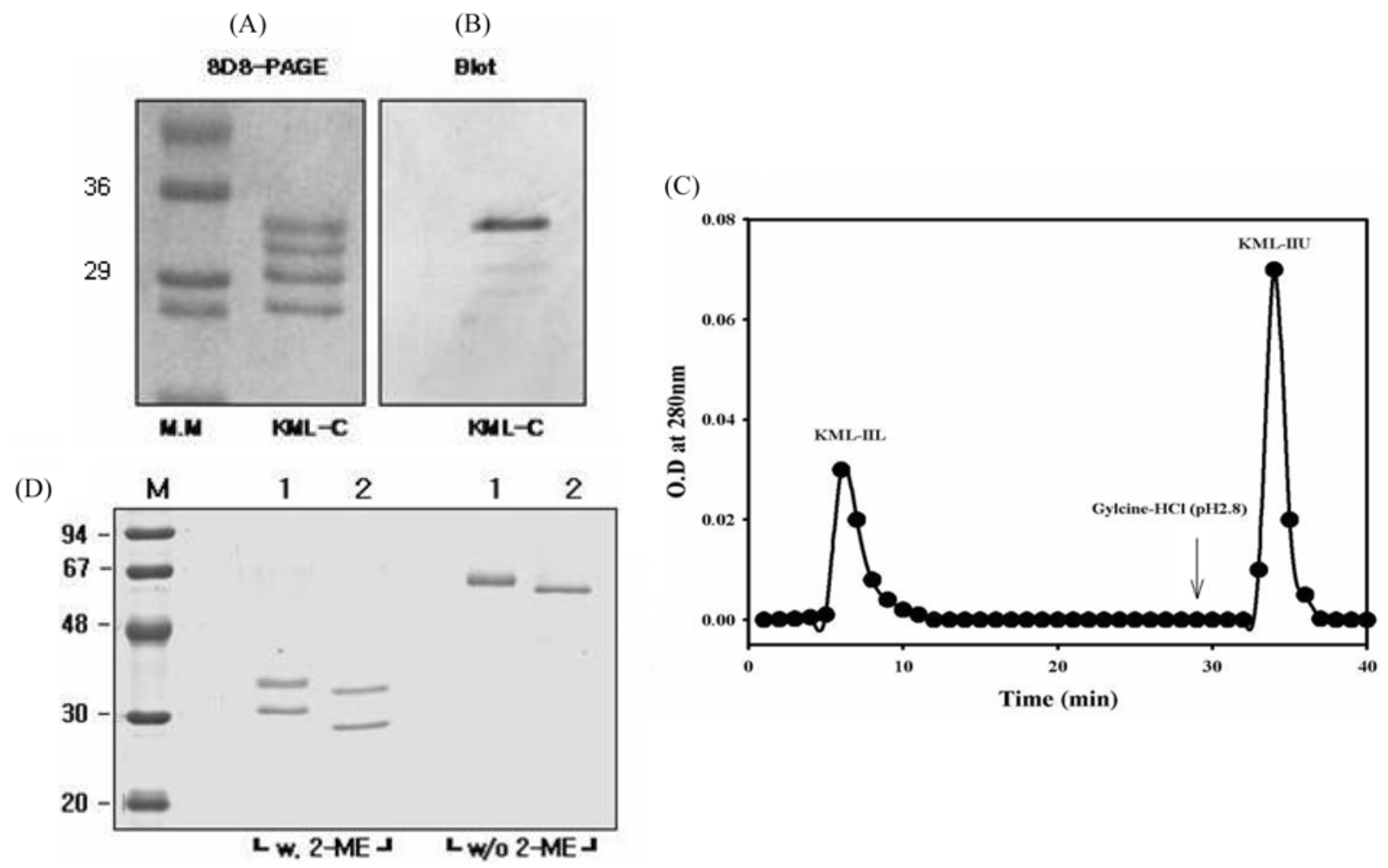

Fig. 1. (A) SDS-PAGE analysis of KML-C under reducing condition, (B) Western blot analysis with the KML-IIU-specific monoclonal antibody. KML-C (1 mg) was separated by $12.5 \%$ SDS-PAGE under reducing condition and stained with Coomassie blue or subjected to Western blot analysis. (C) Isolation of two isolectins from KML-C by immuno-affinity chromatography. The lectin mixture (KML-C) purified by acid-treated Sepharose was applied on a Sepharose column conjugated with KML-IIU-specific monoclonal antibodies. The unbound protein (KML-IIL) was harvested and then the bound protein (KML-IIU) was eluted with $0.1 \mathrm{M}$ glycine-HCl buffer (pH 2.8). (D) SDS-PAGE analysis of two isolectins isolated from KML-C under non-reducing or reducing (with 2-mercaptoethanol, 2-ME) conditions. The lectins (1 mg) were separated in 12.5\% SDS-polyacrylamide gel and stained with Coomassie Brilliant blue. Lanes: M. molecular marker in $\mathrm{kDa}$; 1. KML-IIU; 2. KML-IIL 
Table 1. Amino Acid compositions of KML-IIU and KML-IIL

\begin{tabular}{ccc}
\hline \multirow{2}{*}{ Amino acid } & \multicolumn{2}{c}{ M\% Amino Acid } \\
\cline { 2 - 3 } & KML-IIU & KML-IIL \\
\hline Asx & 11.8 & 10.9 \\
Glx & 10.29 & 11.3 \\
Ser & 11.02 & 10.39 \\
Gly & 8.64 & 10.70 \\
His & 0.96 & 1.22 \\
Arg & 6.97 & 6.39 \\
Thr & 9.68 & 8.43 \\
Ala & 5.86 & 6.69 \\
Pro & 5.28 & 5.01 \\
Tyr & 1.48 & 1.52 \\
Val & 6.56 & 6.20 \\
Met & 1.13 & 1.36 \\
Ile & 5.59 & 5.29 \\
Leu & 8.12 & 8.07 \\
Phe & 3.06 & 3.53 \\
Lys & 2.61 & 1.53 \\
\hline
\end{tabular}

Cystein and Tryptophan were not determined. Composition is expressed as weight of each protein.



Fig. 2. Hemagglutination of human erythrocytes (type B) treated with Korean mistletoe lectins. $50 \mathrm{ml}$ of samples in serial dilution were mixed with $50 \mathrm{ml}$ of erythrocyte suspension in PBS (2\% of blood volume) and incubated for $1 \mathrm{~h}$ at room temperature. Untreated erythrocytes were used as control.

the KML-IIU showed higher contents of Thr, Lys, and Asx, the KML-IIL contained Gly, Glx, and Ala more. As indicated in Table 2, the two isolectins of KML-C showed stronger affinities to lactose than the two sugars explained above. This seems to be a reason why the isolectins were isolated together because the KML-C was separated using an acid-treated Sepharose column. The lectins were then tested for their sugar-binding activities through a hemagglutination assay using human erythrocytes. The two isolectins were similar to each other in hemagglutination activities and also to the KML-C, a mixed form of the two as shown in Fig. 2. In
Table 2. Inhibition of lectin-mediated hemagglutination by sugars

\begin{tabular}{cccc}
\hline \multirow{2}{*}{ Lectins } & \multicolumn{3}{c}{ Minimum concentration of sugars $(\mu \mathrm{M})$} \\
\cline { 2 - 4 } & Galactose & Lactose & $\begin{array}{c}\text { N-acetyl } \\
\text { galactosamine }\end{array}$ \\
\hline KML-IIU & 12.5 & 3.125 & 6.25 \\
KML-IIL & 12.5 & 3.125 & 6.25 \\
\hline
\end{tabular}

Inhibition of hemagglutination of the isolectins was tested by adding different kinds of sugars in various concentrations to determine specificities of the lectins. $25 \mu \mathrm{l}$ of various concentrations of sugars were mixed with $25 \mu \mathrm{l}$ of KML-IIU or KML-IIL $(32 \mathrm{mg} / \mathrm{ml})$ and pre-incubated for $30 \mathrm{~min}$ at room temperature. $50 \mu \mathrm{l}$ of human erythrocytes ( $2 \%$ suspension) were then added and incubated for $1 \mathrm{~h}$ at room temperature.

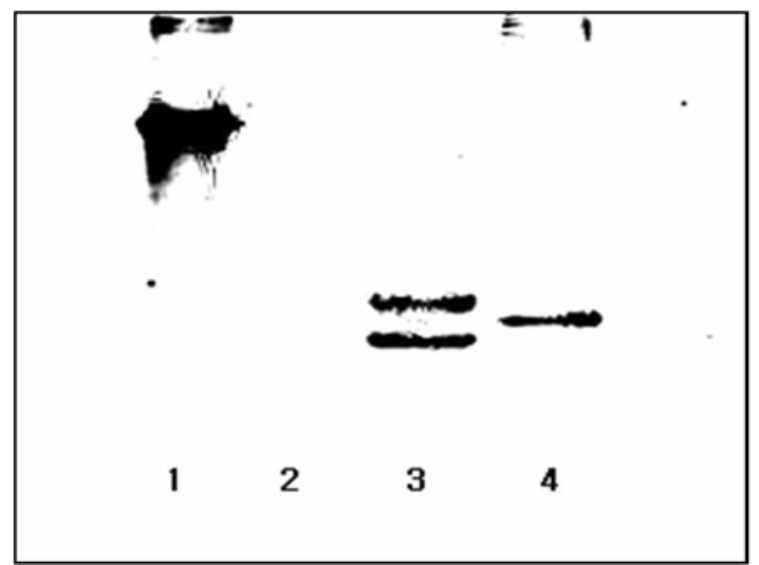

Fig. 3. DIG Glycan detection of KML-IIU and KML-IIL to identify glycoprotein. The lectins $(40 \mathrm{mg})$ were oxidized and labeled with digoxigenin (DIG) according to the manufacturer's instruction. The labeled lectins ( $1 \mathrm{mg}$ per lane) were separated on the $12.5 \%$ SDSpolyacrylamide gel and transferred to nitrocellulose membrane. The conjugated DIG was then detected by an enzyme immunoassay. Transferrin and creatinase were used as control-glycoprotein (+ con) and non-glycoprotein control (- con) respectively. $1 .+$ con, 2. - con, 3. KML-IIU, and 4. KML-IIL.

addition, the two isolectins showed strong affinities to both Gal and GalNAc, which is typical in ML-II type lectins. However, the isotype lectins demonstrated higher binding activities to lactose than to those sugars (Table 2). Glycosylation of the two mistletoe lectins was determined using a method to detect glycans of the lectins after labeling with digoxigenin. As demonstrated in Fig. 3, glycosylation patterns of the two lectins were different: the KML-IIL was glycosylated only on the B subchain unlike the KML-IIU which was glycosylated on both subchains.

Biological activities of the lectins. Mistletoe extracts have been increasingly used for cancer treatment. One of the major bioactive components of the mistletoe extracts was known to be a lectin. Several studies have suggested that anticancer 
Table 3. Comparison of cytotoxicity against various tumor cells between KML-IIU and KML-IIL.

\begin{tabular}{cccc}
\hline \multirow{2}{*}{ Name } & \multirow{2}{*}{ Origin } & \multicolumn{2}{c}{ ED $_{50}$ value $(\mathrm{ng} / \mathrm{ml})$} \\
\cline { 3 - 4 } & & KML-IIU & KML-IIL \\
\hline Sarcoma-180 & Mouse & 29 & 0.2 \\
U937 & Human & 20 & 0.3 \\
3T3-A31 & Mouse & 25.5 & 1.1 \\
P388D1 & Mouse & 30 & 0.3 \\
L1210 & Mouse & 28 & 0.6 \\
HL-60 & Human & 30 & 0.8 \\
Colon-M31 & Mouse & 42 & 1.3 \\
RAW264.7 & Mouse & 19.8 & 1.2 \\
\hline
\end{tabular}

Cells $\left(1-5 \times 10^{4}\right.$ cells/well $)$ were incubated with indicated concentrations of lectins for $48 \mathrm{~h}$ in $96-$-well-plates. The cell viability was measured by XTT method. The data were represented as $\mathrm{ED}_{50}$ values in triplicate.

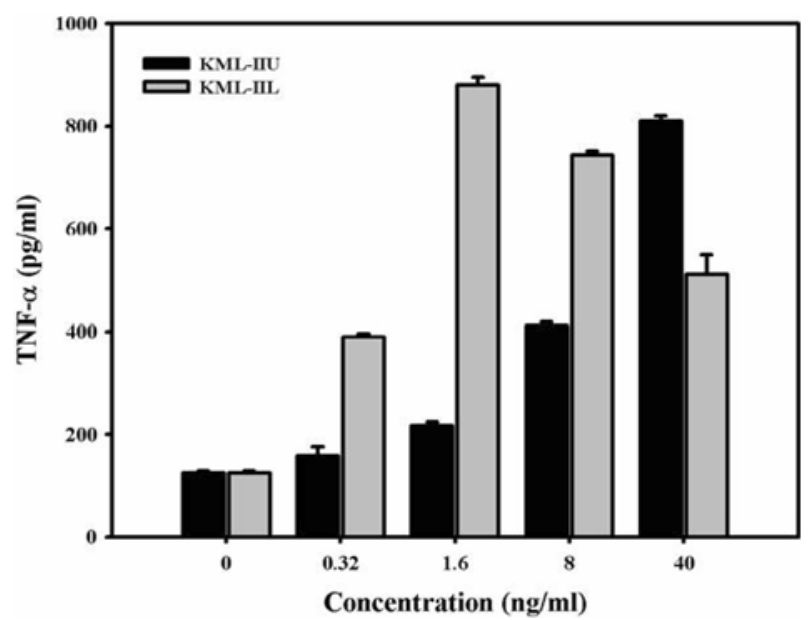

Fig. 4. TNF- $\alpha$ induction by mistletoe lectins. Thioglycollateelicited peritoneal macrophages $\left(1 \times 10^{6}\right)$ were incubated with the indicated concentration of KML-IIU or KML-IIL for $24 \mathrm{~h}$, and TNF- $\alpha$ released to the medium was measured by ELISA. These data are from three independent experiments.

activities of the mistletoe lectins were attributed to cytotoxic properties and immunomodulatory effects of the lectins (Hajito et al., 1990; Dietrich et al., 1992; Beuth et al., 1993; Janssen et al., 1993; Büssing et al., 1996; Büssing et al., 1999). Therefore, for determining bioactivities of the lectins, cytotoxicities and cytokine inducing activities were tested.

Cytotoxic effects of the KML-IIU and the KML-IIL were investigated on various human and mouse cell lines. As shown in Table 3, both of the mistletoe lectins showed strong cytotoxicities to all the cancer cell lines tested. The KML-IIL, however, was much stronger in cytotoxic properties than the KML-IIU; the KML-IIL was 17 to 145 -fold more toxic to the cells than the KML-IIU depending on the kinds of cell lines. The lectins were also cytotoxic to primary mouse splenocytes, suggesting that the lectins were not cancer cell-specific in cell killing activities (data not shown). The lectins were then studied for their activities in TNF- $\alpha$ release from mouse peritoneal macrophages in an endotoxin-free condition (Fig. 4). Although both of the lectins induced TNF- $\alpha$ secretion from the macrophage cells, the KML-IIL, like the case in cytotoxicity, was more potent than the KML-IIU.

Although the isolectins were similar in hemagglutination activity and sugar specificity, biological properties of the lectins were significantly different from each other. The KML-IIL was 17 to 145 times more toxic than the KML-IIU to various human and mice cancer cell lines. These diversities in cell killing activities of the isolectins were shown even similar affinities to Gal and GalNAc (Fig. 2), suggesting that cytotoxicity of the lectin is independent of the concentration of Gal or GalNAc on cell surface. Although glycosylation on the KMLIIU but absence of glycosylation on the KML-IIL A subchain may contribute for the differences in biological properties of the two isolectins, this possibility is certainly to be confirmed by further experiments.

A therapeutic index of the immunotoxin made of a ricin lectin was significantly improved in tumor-bearing mice when the subchain A was deglycosylated (Thorpe et al., 1988). This result suggests that glycosylation affects on the bioactivity of the ricin lectin. It has been well known that carbohydrate moieties on the cell surface polypeptides influence characteristics of the proteins like conformational ability, protease resistance, charge, and water binding capacity (Cumming, 1991). In other report, however, a plant-derived lectin and its recombinant version have no detectable differences in biological activities (Eck et al., 1999), suggesting that glycosylation may not affect on the bioactivities of the lectin. Considering the controversial results discussed above, exact contribution of glycosylation on bioactivities of plant-derived lectins is still in question. Amino acid sequencing and gene cloning of the KML-IIU and the KML-IIL are currently underway. Further structural and functional studies using the wild type isolectins and the recombinant counterparts may clarify the issue.

In conclusion, we report two isotypes of Korean mistletoe lectin having the same sugar specificity but very different in cancer cell killing activity and cytokine induction capability. Although the structure/function correlation between the KML-IIU and the KML-IIL has not been elucidated in detail here, this correlation may be of great importance and be a topic for further investigation in anticancer activities and in immunomodulatory activities. The results suggest the Korean mistletoe isolectins have a great potential to be developed as therapeutic agents of cancer.

Acknowledgments. This study was supported by the grant from 97 Good Health Research and Development Project, Ministry of Health \& Welfare, R.O.K. We would like to thank Korea Basic Science Institute (KBSI) for their technical supports on Amino Acid analysis. 


\section{References}

Bantel, H., Engels, I. H., Voelter, W., Schulze-Osthoff, K. and Wesselborg, S. (1999) Mistletoe lectin activates caspase-8/FLICE independently of death receptor signaling and enhances anticancer drug-induced apoptosis. Cancer Res. 59, 2083-2090.

Beuth, J., Ko, H. L., Gabius, H. J., Burrichter, H., Oette, K. and Pulverer, G. (1992) Behavior of lymphocyte subsets and expression of activation markers in response to immunotherapy with galactoside-specific lectin from mistletoe in breast cancer patients. Clin. Investig. 70, 658-661.

Beuth, J., Ko, H. L., Tunggal, L., Geisel, J. and Pulverer, G. (1993) Comparative studies on the immunoactive action of galactosidespecific mistletoe lectin. Pure substance compared to the standardized extract. Arzneimittelforschung 43, 166-169.

Büssing, A., Suzart, K., Bergmann, J., Pfüller, U., Schietzel, M. and Schweizer, K. (1996) Induction of apoptosis in human lymphocytes treated with Viscum album L. is mediated by the mistletoe lectins. Cancer Lett. 99, 59-72.

Büssing, A., Stein, G. M., Pfüller, U. and Schietzel, M. (1999) Differential binding of toxic lectins from Viscum album L., ML I and ML III, to human lymphocytes. Anticancer Res. 19, 50955099.

Cumming, D. A. (1991) Glycosylation of recombinant protein therapeutics: Control and functional implications; in Glycobiology, pp. 115-130, IRL Press, Oxford, England.

Dietrich, J. B., Ribereau-Gayon, G., Jung, M. L., Franz, H., Beck, J. P. and Anton, R. (1992) Identity of the N-terminal sequences of the three A chains of mistletoe (Viscum album L.) lectins: homology with ricin-like plant toxins and single-chain ribosomeinhibiting proteins. Anticancer Drugs 3, 507-511.

Eck, J., Langer, M., Möckel, B., Baur, A., Rothe, M. and Lentzen, H. (1999) Cloning of the mistletoe lectin gene and characterization of the recombinant A-chain. Eur. J. Biochem. 264, 775-784.

Eck, J., Langer, M., Möckel, B., Witthohn, K., Zinke, H. and Lentzen, H. (1999) Characterization of recombinant and plantderived mistletoe lectin and their B-chains. Eur. J. Biochem. 265, 788-797.

Eschenburg, S., Krauspenhaar, R., Mikhailov, A., Stoeva, S., Betzel, C. and Voelter, W. (1998) Primary structure and molecular modeling of mistletoe lectin I from Viscum album. Biochem. Biophys. Res. Commun. 247, 367-372.

Franz, H., Ziska, P. and Kindt, A. (1981) Isolation and properties of three lectins from mistletoe (Viscum album L.). Biochem. J. 195, 481-484.

Friess, H., Beger, H. G., Kunz, J., Funk, N., Schilling, M. and Buchler, M. W. (1996) Treatment of advanced pancreatic cancer with mistletoe: results of a pilot trial. Anticancer Res. 16, 915920.

Goodwin, C. J., Holt, S. J., Downes, S. and Marshall, N. J. (1995) Microculture tetrazolium assays: a comparison between two new tetrazolium salts, XTT and MTS. J. Immunol. Meth. 179, 95-103.

Hajito, T., Hostanska, K. and Gabius, H. J. (1989) Modulatory potency of the beta-galactoside-specific lectin from mistletoe extract (Iscador) on the host defense system in vivo in rabbits and patients. Cancer Res. 49, 4803-4808.

Hajito, T., Hostanska, K., Frei, K., Rordorf, C. and Gabius, H. J. (1990) Increased secretion of tumor necrosis factors alpha, interleukin 1, and interleukin 6 by human mononuclear cells exposed to beta-galactoside-specific lectin from clinically applied mistletoe extract. Cancer Res. 50, 3322-3326.

Janssen, O., Scheffler, A. and Kabelitz, D. (1993) In vitro effects of mistletoe extracts and mistletoe lectins. Cytotoxicity towards tumor cells due to the induction of programmed cell death (apoptosis). Arzneimittelforschung 43, 1221-1227.

Kang, T. B., Yoon, Y. J., Kim, J. B., Song, S. K., Lee, K. H. and Kwak, J. H. (2001) Preliminary toxicity and general pharmacology of KML-IIU, a purified lectin from Korean mistletoe (Viscum album coloratum). Pharmaceutical Soc. Korea 45, 251-257.

Krauspenhaar, R., Eschenburg, S., Perbandt, M., Kornilov, V., Konareva, N., Mikailova, I., Stoeva, S., Wacker, R., Maier, T., Singh, T., Mikhailov, A., Voelter, W. and Betzel, C. (1999) Crystal structure of mistletoe lectin I from Viscum album. Biochem. Biophys. Res. Commun. 257, 418-424.

Laemmli, U. K. (1970) Cleavage of structural proteins during the assembly of the head of bacteriophage T4. Nature 227, 680-685.

Lee, H. S., Kim, Y. S., Kim, S. B., Choi, B. E., Woo, B. H. and Lee, K. C. (1999) Isolation and characterization of biologically active lectin from Korean mistletoe, Viscum album var. Coloratum. Cell Mol. Life Sci. 55, 679-682.

Park, C. H., Lee, D. W., Kang, T. B., Lee, K. H., Yoon, T. J., Kim, J. B., Do, M. S. and Song, S. K. (2001) cDNA cloning and sequence analysis of the lectin genes of the Korean mistletoe Viscum album coloratum). Mol. Cells 12, 215-220.

Ribereau-Gayon, G., Dumont, S., Muller, C., Jung, M. L., Poindron, P. and Anton, R. (1996) Mistletoe lectins I, II and III induce the production of cytokines by cultured human monocytes. Cancer Lett. 109, 33-38.

Ribereau-Gayon, G., Jung, M. L., Frantz, M. and Anton, R. (1997) Modulation of cytotoxicity and enhancement of cytokine release induced by Viscum album $L$. extracts or mistletoe lectins. Anticancer Drugs 8, 3-8.

Schink, M. (1997) Mistletoe therapy for human cancer: the role of the natural killer cells. Anticancer Drugs 8, S47-51.

Schumacher, U., Adam, E., Kretzschmar, H. and Pfüller, U. (1994) Binding patterns of mistletoe lectins I, II and III to microglia and Alzheimer plaque glycoproteins in human brains. Acta Histochem. 96, 399-403.

Schumacher, U., Stamouli, A., Adam, E., Peddie, M. and Pfüller, U. (1995) Biochemical, histochemical and cell biological investigations on the actions of mistletoe lectins I, II and III with human breast cancer cell lines. Glycoconj. J. 12, 250-257.

Smith, P. K., Krohn, R. I., Hermanson, G. T., Mallia, A. K., Gartner, F. H., Provenzano, M. D., Fujimoto, E. K., Goeke, N. M., Olson, B. J. and Klenk, D. C. (1985) Measurement of protein using bicinconinic acid. Anal. Biochem. 150, 76-85.

Steuer-Vogt, M. K., Bonkowsky, V., Ambrosch, P., Scholz, M., Neiss, A., Strutz, J., Hennig, M., Lenarz, T. and Arnold, W. (2001) The effect of an adjuvant mistletoe treatment programme in resected head and neck cancer patients: a randomised controlled clinical trial. Eur. J. Cancer 37, 23-31.

Thorpe, P. E., Wallace, P. M., Knowles, P. P., Relf, M. G., Brown, A. N., Watson, G. J., Blackey, D. C. and Newell, D. R. (1988) Improved antitumor effects of immunotoxins prepared with deglycosylated ricin A-chain and hindered disulfide linkages. Cancer Res. 48, 6396-6403.

Wu, A. M., Chin, L. K., Franz, H., Pfüller, U. and Herp, A. (1992) Carbohydrate specificity of the receptor sites of mistletoe toxic lectin-I. Biochim. Biophys. Acta 1117, 232-234.

Yoon, T. J., Yoo, Y. C., Kang, T. B., Shimazaki, K., Song, S. K., Lee, 
K. H., Kim, S. H., Park, C. H., Azuma, I. and Kim, J. B. (1999) Lectins isolated from Korean mistletoe (Viscum album coloratum) induce apoptosis in tumor cells. Cancer Lett. 136, 3340.

Yoon, T. J., Yoo, Y. C., Kang, T. B., Her, E., Kim, S. H., Kim, K., Azuma, I. and Kim, J. B. (2001) Cellular and humoral adjuvant activity of lectins isolated from Korean mistletoe (Viscum album colaratum). Inter. Immunopharm. 1, 881-889.

Yoon, T. J., Yoo, Y. C., Kang, T. B., Song, S. K., Lee, K. B., Her, E., Song, K. S. and Kim, J. B. (2003) Antitumor activity of the Korean mistletoe lectin is attributed to activation of macrophages and NK cells. Arch. Pharm. Res. 26, 861-867. 